\title{
Ireland's Ready to Learn White Paper: Then and Now
}

\author{
Natasha O’Donnell \\ Herbert Montessori Primary School, Ireland
}

\begin{abstract}
Using Critical Discourse Analysis (CDA), guided by the work of Ball and Fairclough, this paper examines Ready to Learn (Department of Education and Science, 1999), Ireland's first policy pertaining to the early education sector. Information regarding the economic, social and political backdrop to the paper publication is provided to inform context of publication. Findings are interesting, particularly with regards to the timeframe and state of enactment, as Ready to Learn proposes radical reforms for the early education sector, particularly in relation to topics which remain a priority in global educational policy today, such as inclusion and quality. This paper highlights a lack of clarity regarding implementation planning and recognises the changes in early years, which is responsible for the sector's current state of evolution, concluding with a brief review of how the early education sector in Ireland looks in 2017, noting the roots of change casts by the Ready to Learn white paper in 1999. CDA proves a useful lens through which to examine Ready to Learn, lending itself to analysis of the language contained in the paper, although it may be worth noting that whilst CDA may be explicit regarding its own position, it leads to open-ended results (Fairclough, 1996).
\end{abstract}

\section{Introduction}

The landscape of early education in Ireland is currently in a state of rapid evolution, with new initiatives and legislation designed to raise standards and establish the key role of early experiences on life-long learning. Currently, we are witnessing such initiatives as a second free pre-school year, the Access and Inclusion Model (AIM) training programme and the Leadership for Inclusion (LINC) programme. The roots of this evolution lie within the publication of the Ready to Learn [13] White Paper, the first Irish document pertaining to the education of children under the age of six years. Ready to Learn is a particularly interesting document, in that it does not conform to the traditional policy process. No Green Paper preceded the publication of Ready to Learn, it largely bases its proposals on the 1998 Report of the National Forum for Early Childhood Education, setting out an agenda to overhaul and greatly develop the early years sector. It even differs from tradition in terms of presentation, reading similarly to a book, rather than using the bullet point approach generally found in Irish educational policy documents. It consists of eleven chapters, each with its own cover page to provide readers with a synopsis of the content, and engages in descriptive discourse around each topic prior to setting out guidelines on how best to proceed. It clearly recognises the need to develop policy and provision, and the need to use research to ensure usage of the best strategies to deliver quality experiences, meeting the needs of all children.

The author wishes to examine Ready to Learn as, over 17 years later, it remains influential throughout the early years sector. Particular attention will be paid to five key areas: quality; curriculum; coordination; inclusion and inspection. The author believes these areas are essential in establishing a high quality sector designed to provide education and care for all children prior to them entering Primary School. These areas in particular continue to be topical, with the sector offering a Síolta Standards Award to quality services and extending Visiting Teacher services to promote coordination. In 2016 a new academic inspectorate body was launched and a new training programme designed to enhance inclusion. Underpinning these areas is the provision of a diverse and accessible curriculum for all children, providing them with the opportunity to fulfil their potential. The Ready to Learn paper will be analysed through the lens of Critical Discourse Analysis (CDA), guided by the work of Ball and Fairclough, exploring what and how language is used in this policy, and how said language influences interpretation. It will also explore the care/education legacy it left in its wake.

\section{Background}

A time and a place...

Ready to Learn remains influential today although it was published during a time which bears little resemblance to today's social, economic and political landscape in Ireland. Fairclough [8] proposed language is best interpreted in the context in which it is used, therefore the author will briefly describe the Irish backdrop at the time of publication, considering the social, economic and political scene in Ireland during this time. A global change in attitude regarding children emerged, bringing about a considerable volume of policy and legislation regarding children's rights. This culminated in the 
almost universal ratification of the 1989 UN Convention on the Rights of the Child. This convention was ratified by Ireland in 1992, and led to the National Childcare Strategy which established Ireland's commitment to safeguarding the rights of children in policies and provisions (Hayes, 2010) [9]. Ireland also found itself experiencing a growing economy which led to a dramatic shift in family life, with women returning to work and families requiring childcare. This demand for childcare revealed a lack of quality and affordability in the early years sector. This coincided with global recognition of school readiness [16] as a strategy to improve equity, giving consideration to all children, especially the disadvantaged and vulnerable [15]. Even now we are in the midst of a cycle where school readiness is strongly linked with human capital, with research indicating improved academic outcomes and positive social competencies enhancing economic development. This notion of school readiness played a significant role in Fianna Fáil's manifesto for the 1997 General Election. The Election saw Fianna Fáil win $39.3 \%$ of the votes, resulting in them leading a coalition with the Progressive Democrats and four Independents. Bertie Ahern became Taoiseach, a post which he would hold until 2008. Ireland's membership of the European Union (E.U.) and joining the single currency market served to further Ahern's popularity as prosperity blossomed. Ireland became an attractive European access point for multi-national investors, and low corporation tax ensured investment flow, with the rate of return on American investment averaging 20\%, the highest in the E.U. Fianna Fáil intertwined the strands of a booming economy, the need for women to re-join the workforce and the importance of early education, ensuring a cyclical link, the provision of childcare enabling women to return to work to bolster the Irish workforce, meeting the demands of the booming economy and leading to increased prosperity. Their proposed commitment to preschool education, the establishment of a National Forum for Early Childhood Education and a desire to enhance the early education sector status continue to be instrumental in educational practice today.

\section{Catalyst for change...}

Once in power the coalition government, under the leadership of Fianna Fáil, set about delivering an early education plan, believing in the long-term advantages to society and the economy. In 1999, the National Childcare Coordinating Agency (NCCA) was established to commence the phased implementation of the National Childcare Strategy. The main aim of the strategy was to ensure the provision of supports and services relating to all aspects of children's development. In 1999, the National Development Plan allocated over $€ 400 \mathrm{~m}$ through the Equal Opportunities Childcare Programme (EOCP) to facilitate the development of the childcare sector, particularly for those considered disadvantaged. The National Voluntary Childcare Collaborative (NVCC) was also established, consisting of organisations with an interest in the promotion of Early Childhood Education and Care. The Department of Education and Science (DES) produced the Ready to Learn White Paper, designed to focus specifically on early education, establishing a comprehensive strategy for the education of children from birth to six years of age. This paper covers a broad range of issues pertaining to early education, including promotion of quality, encouraging parental involvement and a system of inspection. There is also great emphasis placed on education for all, providing provisions to enable the inclusion of children with special educational needs (SEN) and those considered disadvantaged, an area considered to yield great investment return. Indeed, according to Hayes [9] educational equity played a significant role in developments within the early education sector and the direction of research in Ireland in the wake of Ready to Learn. The paper places emphasis on quality, determining the production of a quality framework would set high quality standards. The paper also proposes the production of a framework regarding curriculum, to ensure improved opportunities for learning experiences across services. It suggests an education inspectorate work alongside the Health Service inspectorate, already in place, and a central agency be created to coordinate services. The paper also promises commitment to several measures to enhance inclusion for children with SEN and those considered disadvantaged, and acknowledges uniformity is not necessarily the key to providing equality, recognising the need for appropriate individual support to enable all children to fulfil their potential.

\section{Methods and Methodology}

\section{Critical Discourse Analysis-what lies beneath?}

Critical Discourse Analysis (CDA) considers the use of intertextuality, interdiscursivity, lexicogrammatical construction, along with the attitudes and judgements behind the language used, and attempts to de-construct the reality presented. In discussing CDA, the author acknowledges Bowe and Ball's [4] idea of the policy cycle, which sees governments adopting a somewhat linear approach, focusing on macro-based theoretical analysis, excluding the voices of teachers, students and parents, therefore potentially increasing the gap between policy and practice. CDA concerns itself 
with exploring language, paying particular attention to how social relations, identity and power are constructed, with the political, economic and social context at the time of publication in mind. Marston [11] also recommends the analysis of the social practices surrounding text production. Ball [1] describes policies as textual interventions into practice, believing the more ideologically abstract the policy the greater the distance from conception to practice.

Discourse is, simply put, the use of language. A person, or agency, can construct a particular understanding based on the use of language. It is also important to note that language is not neutral. It can be used explicitly or implicitly to convey attitude, authority or intention [2]. Discourse can “...evaluate...ascribe, purpose...justify...” [18]. Discourse analysis can assist in the understanding of "why people interact with one another the way they do..." [10]. Ball [1] considers most policies to be ramshackle, a bricolage process, taking information and ideas from elsewhere and amending then to suit local needs. They present "truths" to reinforce the ideology presented and, as Ball [2] has stated, they idealise solutions to problems. Richardson and Gill [14] reinforces this idea, believing discourse is organised to be persuasive. In examining some of the key components of Ready to Learn the author will use CDA to explore the meaning behind the language used and attempt to de-mystify the ideologies presented [12], whilst bearing in mind the open-endedness of CDA results [8]. Consideration will be given to intertextuality, used to establish credibility, presuppositions, implications, the use of verbs to construct desired realities, and the use of key words to inscribe attitudes and evoke emotions. An exploration of the lexico-grammatical construction will also be provided, discussing the use of past, present and future tenses. This analysis will be conducted while bearing in mind Ball's [2] notion that we must consider not just whose ideas are being validated, but whose ideas are not being validated, alongside Fairclough's [8] idea that what is absent from a text may be just as significant as what it contains.

\section{Analysis of Findings Intertextuality: the good, the bad and the credible}

Ball [2] suggests that policies embody claims to speak with authority. Credibility plays a key role in all aspect of society. Certain newspapers, universities, even people, are considered more credible than others. This credibility influences our thinking, increasing the likelihood of credible institutes and people gaining our support. For the DES to gain support for Ready to Learn they needed to establish credibility, and they set about doing so straight from the document's foreword. While the document author is the DES, a powerful group body, the author of the foreword is Micheál Martin, Minister for Education and Science 1997-2000. He introduced many education initiatives and increased educational spending, helping increase his public popularity. However, Martin does not merely sit on his laurels, he also refers to the Irish Government's 2001 Action Plan for the Millennium and the 1998 Partnership 2000: Childcare. He gains further credence by referring to existing provisions, both nationally and internationally, and extensive research, suggesting "we must take what is best...and incorporate it into our early childhood education system.” (pp.6). Also interesting is the placement of these references throughout the foreword, ensuring a sense of credibility is present in both the second and final sentences, along with the central paragraph.

An attempt to establish credibility is present throughout the text. Excluding the foreword and reference list Ready to Learn is a 103-page document, within which there are 95 quotes. The credibility trail doesn't stop there, it also refers to other Departments of the Irish government, Acts and Programmes, and that's before considering international references. This vast volume of information is shown in Table 1. The use of so many references from such a variety of sources, both national and international, and so many texts weaved within the document, suggests that Ready to Learn must deserve credibility and support. That certainly appears to be the point which the DES are attempting to make. They seem determined to highlight the links between this document and existing provisions and research, filling the reader with confidence and belief in Ready to Learn, while failing to address the practicalities of implementation: the investment; the repercussions for those working in the sector; the need for guidelines; the timeframe.

Table 1. Incidents of intertextuality

\begin{tabular}{|l|l|}
\hline References Irish & Frequency \\
\hline $\begin{array}{l}\text { Departments of the } \\
\text { Government }\end{array}$ & 112 \\
\hline Other Irish Organisations & 29 \\
\hline Government Acts & 69 \\
\hline Pilot Projects/ Schemes & 8 \\
\hline Researcher/Author & 12 \\
\hline International Organisations & 35 \\
\hline International Research & \\
\hline
\end{tabular}

Table 1 shows the range of sources and the frequency with which they appear.

\subsection{The "value" of Interdiscursivity}

Economic status is often influential in educational policy, especially in times of fiscal austerity, with research suggesting links between 
education and consumerism [3]. When examining the relationship between education and consumerism it is important to remember that Ready to Learn was produced in 1999, a time when Ireland was experiencing an economic boom and budgets were awaited with expectation rather than fear. In their 2001 Action Plan for the Millennium, the Irish Government predicted a budget surplus of $£ 1.7$ billion and stated Ireland to have one of the lowest public debt ratios in Europe. Ready to Learn is written with financial promise, even referring to the OECD philosophy of greater educational investment equating to economic merit. The word "cost" is mentioned only 28 times throughout the entire document and "value" appears on 12 occasions. An attempt to reaffirm the link between educational expenditure and economic prosperity is present, the word "capital” being used on 6 occasions, 3 of which appear within the term "human capital", placing capital value on the acquired skills of people, a skilled workforce equating to greater capital value. There are also assurances of tangible supports, subsidies for suitable premises payable to providers and a free pre-school year promised to parents. This affirmation of economic value is clearly intended to warrant public endorsement. Interesting then, is Fairclough's [8] suggestion of the importance of what is absent from a text, as there is a significant lack of information regarding funding of proposed provisions throughout the paper. The author also found incidents of policy borrowing, the use of ideas and proposals present in other documents, which may be influenced by an attempt to improve economic competitiveness [7].

\subsection{Reality (de)constructed: Presupposition and Implication}

The DES took great care to illustrate an ideological picture through their use of language in Ready to Learn, one in which society would be a willing participant. They created a sense of a wonderful reality being imminent, leaving no doubt that it would happen.

Table 2. Terms used to imply positive change

\begin{tabular}{|l|l|}
\hline $\begin{array}{l}\text { Words used with "will"/will be" } \\
\text { to suggest positive change }\end{array}$ & Frequency \\
\hline Encourage & 9 \\
\hline Provide & 9 \\
\hline Achieve & 8 \\
\hline facilitate & 5 \\
\hline Benefit & 4 \\
\hline Develop & 4 \\
\hline Improve & 3 \\
\hline Promote & 3 \\
\hline Enhance & 2 \\
\hline
\end{tabular}

Table 2 shows the frequency of words combined with future tense verbs, to create a sense of "a change for the better" following enactment. The foreword contains phrases such as "seeks to support" and "will be achieved", a trend which continues throughout the document, with phrases such as "can make", "seeks to", and "will ensure" scattered throughout the text. Not only is there the suggestion of these verbs resulting in change, we must also consider the words with which these verbs are partnered, words such as "achieve” and "encourage", creating a sense of the positive change which will occur as a result of enactment. A summary of this information is presented in Table 2.

Negativity is ominous by its near absence, with the words "reduced" and "prevented" appearing only once. This is further highlighted by comparing the frequency of "will” (235 occurrences) and "will be" (207 occurrences) with "will not" (5 occurrences). There is also a sense of urgency attached to "is", combining it with "crucial" (6 occurrences), "essential” (6 occurrences) and "vital” (5 occurrences). There is evidence of lexicogrammatical construction in the use of tenses. The words "is" and "are" are used frequently, placing us in the present, making us part of what is occurring right now. There is also significantly greater use of future tense over past tense, providing a sense of looking forward. This information is presented in Table 3.

Table 3. The appearance of positive versus negative terms combined with verb tense

\begin{tabular}{|l|l|l|l|}
\hline Positive & Frequency & Negative & Frequency \\
\hline $\begin{array}{l}\text { Will or } \\
\text { will be }\end{array}$ & 442 & will not & 5 \\
\hline $\begin{array}{l}\text { Was or } \\
\text { were }\end{array}$ & 80 & $\begin{array}{l}\text { was not } \\
\text { or } \\
\text { were not }\end{array}$ & 4 \\
\hline $\begin{array}{l}\text { Is or } \\
\text { are }\end{array}$ & 819 & $\begin{array}{l}\text { is not or } \\
\text { are not }\end{array}$ & 22 \\
\hline
\end{tabular}

Table 3 shows the frequency of positive versus negative terms and the use of verb tenses.

\subsection{Attitude Problem: Provoking Positivity}

Language is rarely neutral and this fact plays an important role in policy writing. Weaved throughout Ready to Learn we find incredibly powerful language which impacts on the reader simply by being present. It leads us to look at the document in a particular way, creating a sense of what can be achieved, presenting a picture of positivity. It is difficult to read the document without becoming excited by the proposals to achieve "education for all", firmly believing in the recognition of the importance of consultation with all involved parties. 
As early as the foreword, Martin refers to the publishing of the document itself as a "milestone" and it is a paper which is embedded with optimism, from improving standards of professional competency to providing a comprehensive strategy for enactment, the language taking on a life of its own. Table 4 below helps identify the language present and frequency of use, in order to assess the implications created. The word "quality" is one of the most frequently used words in the document, appearing on 191 occasions. It offers assurances, being instantly associated with positive experiences, assurances of quality services for early education and quality standards to be upheld through inspection. Clearly the aim of this paper is to provide the very best services. The word "standards" appears on 93 occasions, "expert" appears on 55 occasions and "qualifications" appears on 53 occasions. There is the question of how the promises of this policy will be achieved, but the reader's mind is put at ease by the use of words such as "support" (141 occurrences) and "consultation" (33 occurrences). The reader's sense of ease is furthered by the addition of the words "effective" (75 occurrences), "benefits" (72 occurrences) and "enhance" (44 occurrences), ensuring the future of early education looks positively bright for all concerned. Positivity outweighs negativity, which is highlighted by the use of "fail"/"failure" a mere 7 times compared to "succeed"/"success" 13 times, almost double the frequency.

Table 4. Words used to evoke positivity

\begin{tabular}{|l|l|}
\hline Words & Frequency \\
\hline quality & 191 \\
\hline support & 141 \\
\hline standards & 93 \\
\hline effective & 75 \\
\hline benefits & 72 \\
\hline expert & 55 \\
\hline qualifications & 53 \\
\hline enhance & 44 \\
\hline consultation & 33 \\
\hline
\end{tabular}

Table 4 shows the most frequently used words within words which evoke positive connotations.

\subsection{The Care and Education Debate}

Fairclough [8] suggested looking for gaps in discourse in order to identify areas for potential change. Despite suggesting they are intertwined, the gap between care and education presented throughout Ready to Learn certainly suggests a need for change. There is an intimation that care and education form a continuum and should not be separated. However, the paper also suggested that the balance between care and education shifts, with the age of the child indicating the balance required.
Furthermore, the paper insists on an integrated approach to care and education, yet discusses them separately on many occasions. This is particularly apparent in discussing the area of inspection, where a dual inspection is suggested, the current health and safety inspector, generally a public health nurse, being accompanied by an educational inspector. This care and education debate rages on in 2017, with those in power continuing to highlight the need for, and importance of, both care and education in the early education sector, yet continuing to separate these entities at policy level. There is also a sense that early education is essential as an intervention for children with SEN and those considered disadvantaged, with children outside of these categories requiring childcare simply to facilitate working parents. While 2017 reveals a greater awareness of the value of early education for all children, regardless of ability, the policy-makers are only now providing training to assist in the implementation of inclusion, in the form of the AIM and LINC programmes. Whilst the combination of "care and education" appears on 12 occasions, the combination of "education and care" appears on 18 occasions, creating a 2:3 ratio. Upon further examination, the individual word "care" appears on 136 occasions, whilst the word "education" appears on 476 occasions, creating a 2:7 ratio. This information is presented in Table 5 . This seems a staggering difference for terms supposedly being given equal weight with regards the role they each play in early years services.

Table 5. Care/Education

\begin{tabular}{|l|l|l|}
\hline Words & Frequency & Ratio \\
\hline care and education & 12 & $2: 3$ \\
\cline { 1 - 2 } education and care & 18 & \\
\hline Care & 136 & $2: 7$ \\
\cline { 1 - 2 } Education & 476 & \\
\hline
\end{tabular}

Table 5 shows the frequency of the words care and education, individually and in combined formats. These terms played a significant role in the 2016 preelection manifestos of many Irish political parties.

\section{Discussions}

This paper set out to analyse the language present throughout the Ready to Learn White Paper, and its influence on interpretation and enactment, using CDA. The author identified the use of references, quotes and citations to establish credibility, key words to express attitudes and evoke judgements, presupposition/implication using factive verbs to construct convincing realities, lexico-grammatical construction through the use of verbs, and even a hint of interdiscursivity pertaining to the early years sector and consumerism [1], most noteworthy in the 
areas of quality and inclusion of those considered disadvantaged. This link between consumerism and those considered disadvantaged is particularly interesting, as this area is considered to yield great investment return. Ready to Learn certainly goes to great lengths to ensure it is viewed as a credible and innovative document, full of promise for the future. It outlines proposals for change in quality; curriculum; coordination; inclusion and inspection, and suggests the co-existence of care and education will enhance the early years sector. It establishes the foundation for enactment but, as stated in the foreword, change "cannot occur overnight" and a "phased approach will be necessary".

\section{Then and Now The rocky road to enactment...}

Ready to Learn certainly establishes its intent to create a high quality early years sector in Ireland and, through clever use of language and reference to other documents, it proposes an ideal reality. The road to enactment starts slowly and, in 2002, the DES invite the OECD Directorate for Education to conduct a review of early childhood policies and services. The OECD recommendations echo those of Ready to Learn: establish a quality framework; centralise policy under one department; train and recruit teachers and assistants specifically for Traveller children. The review also suggests free preschool education for all four-year-old children. Now, let's examine enactment in the areas of quality; curriculum; coordination; inclusion and inspection. The first step taken pertains to coordination, specifically the allocation of a lead role to a single organisation. In 2002, the Centre for Early Childhood Development and Education (CECDE) was established, to coordinate and implement recommendations from Ready to Learn. Unfortunately, due to an economic collapse felt globally, the CECDE could not be funded and ceased operating in 2008. Despite a short tenure, the CECDE legacy remains evident in the Early Years sector today particularly its involvement in the consultation process and drafting of a quality framework for the sector, published as Síolta in 2006. The difficulty remains, Síolta is a framework and therefore open to interpretation which may reflect a personal agenda. In 2009, the National Council for Curriculum and Assessment (NCCA) published Aistear, a curriculum framework. Again, this framework leaves room for interpretation and, as schools are complex and internally different, therefore interpretation may differ greatly. Also, worth considering is Colebatch's [5] notion that enactment practices may be based on pedagogy, yet to facilitate the use of Aistear nationally in all preschool services, there is an absence of any reference to particular pedagogies.
Parallel to the work of the CECDE there were other legal initiatives, such as the 2001 Children's Act, which centred on the legal rights of children, and the 2004 Education of Persons with Special Educational Needs (EPSEN) Act. Whilst the EPSEN Act supports many of the recommendations of Ready to Learn, much like CECDE, it suffered greatly due to the economic crisis, resulting in implementation being placed on hold. Indeed, even today, something as basic as an Individual Education Plan (IEP) is not a mandatory entitlement for children with SEN, so there is no stipulation for providing a modified curriculum.

Table 6. The implementation status of proposed aims of Ready to Learn

\begin{tabular}{|c|c|c|}
\hline $\begin{array}{l}\text { Key } \\
\text { Area }\end{array}$ & $\begin{array}{l}\text { Aim stated in Ready } \\
\text { to Learn (1999) }\end{array}$ & Status \\
\hline$\frac{\stackrel{\nexists}{\Xi}}{\frac{\pi}{\sigma}}$ & $\begin{array}{l}\text { To create a Quality } \\
\text { framework, } \\
\text { encompassing } \\
\text { curriculum, } \\
\text { methodologies, staff } \\
\text { qualifications and } \\
\text { training. }\end{array}$ & $\begin{array}{l}\text { Síolta Quality } \\
\text { Framework, } 2006 \\
\text { (7 years post Ready to } \\
\text { Learn) }\end{array}$ \\
\hline 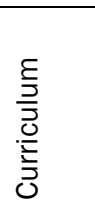 & $\begin{array}{l}\text { To create a } \\
\text { curriculum } \\
\text { framework, } \\
\text { ensuring structure, } \\
\text { high quality and a } \\
\text { readiness to learn. }\end{array}$ & $\begin{array}{l}\text { Aistear Curriculum } \\
\text { Framework, 2009 } \\
\text { (10 years post Ready to } \\
\text { Learn) }\end{array}$ \\
\hline 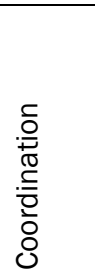 & $\begin{array}{l}\text { To allocate a lead } \\
\text { role to a single } \\
\text { organisation }\end{array}$ & $\begin{array}{l}\text { CECDE } 2002-2008 \\
\text { Numerous agencies are } \\
\text { currently involved in the } \\
\text { early years sector } \\
\text { ( } 3 \text { years post Ready to } \\
\text { Learn) }\end{array}$ \\
\hline 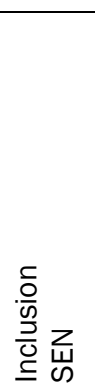 & $\begin{array}{l}\text { To ensure trained } \\
\text { and experienced } \\
\text { staff are positioned } \\
\text { to provide support. } \\
\text { To ensure a } \\
\text { modified education } \\
\text { plan is in place to } \\
\text { assist each child in } \\
\text { fulfilling their } \\
\text { potential. }\end{array}$ & $\begin{array}{l}\text { EPSEN Act, } 2004 \\
\text { (5 years post Ready to } \\
\text { Learn) } \\
\text { Phased implementation } \\
\text { is on-going } \\
\text { AIM training programme, } \\
2016 \\
\text { (17 years post Ready to } \\
\text { Learn) }\end{array}$ \\
\hline 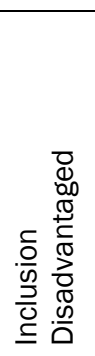 & $\begin{array}{l}\text { To encourage and } \\
\text { support } \\
\text { disadvantaged } \\
\text { communities to } \\
\text { establish their own } \\
\text { pre-school } \\
\text { programmes. } \\
\text { To avoid } \\
\text { stigmatism. }\end{array}$ & $\begin{array}{l}\text { ECCE, } 2010 \text { ( } 1 \text { free pre- } \\
\text { school year) } \\
\text { (11 years post Ready to } \\
\text { Learn) } \\
\text { ECCE, } 2016 \text { ( } 2 \text { free pre- } \\
\text { school years) } \\
\text { (17 years post Ready to } \\
\text { Learn) } \\
\text { AIM (as for SEN) }\end{array}$ \\
\hline
\end{tabular}




\begin{tabular}{|l|ll|l|}
\hline & $\begin{array}{l}\text { To develop a dual } \\
\text { inspection system }\end{array}$ & $\begin{array}{l}\text { Education Inspectorate, } \\
\text { 2016 to work separately } \\
\text { of the pre-existing Health } \\
\text { (education }\end{array}$ \\
Service Inspectorate \\
(17 years post Ready to \\
Learn)
\end{tabular}

As for Ready to Learn recognising the importance of trained and experienced staff, the government launched a training programme, Access and Inclusion (AIM) in June 2016, over 16 years since the publication of Ready to Learn. The LINC training programme also launched in 2016, the idea being that every early education setting would have a member of staff trained to facilitate inclusion, although it must be noted that teacher access to training is restricted to one teacher per early years setting. An element of contradiction was found in Ready to Learn, regarding provision for those considered disadvantaged, with recommendations to encourage the establishment of community preschool programmes whilst offering inclusion in preschool services to avoiding stigmatism. Hayes [9] believed concerns regarding equality played a significant role in developments in the Early Years sector and 2009 saw the launch of the Early Childhood Care and Education (ECCE) programme, offering one-year free preschool placement to all children, based solely on age. September 2016 sees the extension of this programme, offering two free years of pre-school to all children based solely on age. It is worth noting that a decade passed between the publication of the Ready to Learn and the initiation of the free preschool year programme. Similarly, 2016 saw the launch of an Education Inspectorate, operating from the DES, separately from the pre-existing Health Service Inspectorate. Once again, having waited over 16 years for enactment, a division between care and education continues to exist. This is sadly not the only apparent division, for there remains numerous agencies involved in the Early Years sector, such as the Department of Education and Skills, the Department of Children and Youth Affairs, the Department of Health, Tusla and the National Council for Curriculum and Assessment. So, if we revisit the areas of quality; curriculum; coordination; inclusion and inspection, and examine the aims within Ready to Learn, we can see the state of enactment, and the timeframe. This information is presented in Table 6. Table 6 shows the proposed aims stated in Ready to Learn (1999) and the current status of these aims, including the time span, ranging from 3 to 17 years.

\section{Conclusion}

There remains the issue of the care/education debate, the status of which is most definitely on- going and the source of much literature. This split is not only unhelpful but somewhat illogical, as effective education will include care, and care should include education. Hayes [9] intimated care and education continue to be discussed as separate entities, and further suggested that should care be reconceptualised as nurture, this may strengthen the perceived value assigned to care. In 2001, the OECD's Start Strong [17] identified care and education as inseparable, insisting both are required to create a quality early years sector. They also proposed the use of the term Early Childhood Education and Care (ECEC) may provide a more balanced representation of care and education. Indeed, as recently as the 2016 Irish General Election, the care/education issue played a significant role in the manifestos of many of the key political parties. Returning to Fairclough's [8] notion of the significance of what is absent from text, when discussing the early years sector the word "teacher" was ominously absent amidst a plethora of alternative words and terms: child care workers; staff; childminders; early years professionals; crèche workers; workers in the childcare sector; workforce in early education and care, ECCE workforce and those who provide childcare services. It would seem 2017 finds many teacher experiencing an identity crisis, thanks to the power of language. Naming is a powerful tool and may even play in part in how we interact. Indeed, the author is reminded of Ball's [1] suggestion that rather than us speaking discourse, it is discourse which speaks us.

Ready to Learn provides some interesting reading, especially with the advantage of hindsight. It relied heavily of references to research which has since been updated, and attempted to deal with so many agendas it left much ambiguity, proving Bowe and Ball's [4] suggestion that interpretation can be increasingly difficult when several agendas are being covered. The author finds particularly fascinating, the sense of urgency created throughout the paper, knowing that over 17 years later there remain components of this policy yet to be enacted, reminiscent of Ball's [1] suggestion that policies are textual interventions into practice. It once again raises his belief that the more ideologically abstract the policy the greater the distance from conception to practice. Corsaro [6] suggested quality early education enriches childhood. This author suggests quality early education holds the key to an enriched society, if we can all read from the same script and interpret it in the same way.

\section{Ominous by its absence...}

The legacy of Ready to Learn is not only visible in the early education landscape but it appears a powerful force, directing the shape of current policies. While we now have a curriculum 
framework and inclusion policy there remains a lack of focus on the working conditions of those employed in the early education sector. Research continues to draw attention to the importance of quality experiences throughout early education, highlighting the critical role of early years in determining a child's future, therefore it would seems logical that early education teachers, who play a crucial role in early experiences, would gain prominence in our society, yet the policy makers pay them little heed, calls for professionalization being buried under policy regarding funding for placement and setting provisions. Perhaps the care element of early education leads to devaluation of the role of early educators, yet it is this finely tuned balance of care and education which demands a highly skilled workforce.

In 2013, following an exposé of poor practice in a number of settings, a National Early Years Quality Agenda was created, aimed at improving the quality of early education. It placed significant focus on qualifications, introducing mandatory minimum requirements enforced in September 2016 (DCYA, 2015) and offering increased government funding to settings employing teachers holding a degree level qualification. Startlingly, research conducted by Pobal in 2015 revealed $86.8 \%$ of early education teachers hold a basic minimum qualification, with a recent bursary fund aimed at enabling early education teachers to achieve a qualification equal to a level 5 on the National Framework of Qualifications (NFQ). This seems to suggest that while the Irish Government may recognise the importance of early education it continues to undervalue early education teachers.

Fairclough describes CDA as a discourse analysis which seeks to systematically explore relationships of causality, to investigate how practices arise from and are ideologically shaped by relations of power and examine how these relations play a role in securing power and hegemony. He also recognises that power is predominantly exercised through consent rather than coercion, therefore seeks to explore the ways in which discourse is shaped by relations of power and ideology and the ways in which discourse shapes these relations. A fundamental aspect of CDA is its belief that discourse is socially embedded, but it also professes to be socially committed [8], wishing to increase the reader's awareness of the ability of language to facilitate the domination of certain people, believing this heightened awareness to be the first step towards emancipation. Bearing this in mind, it is interesting to note that, despite ambitious policy plans, early education teachers remain one of the most poorly remunerated amongst professional groups [19].
The truth according to CDA...

CDA is concerned with exploring language, with particular attention to how social relations, identity and power are constructed, with social context at the time of publication in mind. Many forms of CDA exist, united by their critical lens, focusing on knowledge, subjects and power relations, examining how they are produced, reproduced and transformed within discourse, and operationalised through the analysis of text in context. They may reveal "truths" presented to reinforce the dominant societal ideology. While the government have been heavily guided by Ready to Learn there remains an aspect of the paper, the absence of a route of progression for those working within the early education sector, which has yet to be addressed. In fact, it is argued by Moloney [19] that the manner of implementation of frameworks, such as Aistear, continues to undermine and negate professional identity, as professionalization of the early education sector requires raising qualification standards which will lead to increased wage demands. Engaging with Foucault's [20] theories regarding language facilitates an historical examination of discourse, identifying how hierarchies help regulate and legitimate the behaviour of people positioned within the field of early education. His theories regarding societal power relationships as expressed through language and practice facilitates the examination of how the world is affected by sources of power. It also recognises the possible existence of many hybrid versions of reality, permitting contrasting positioning of subjectivity, particularly relevant to the numerous identities of early education teachers and how those identities vary from personal to societal and political perceptions. Also fascinating is Foucault's [20] view of a statement as a function rather than a linguistic structure, recognising discourse as statements which are systematically organised, creating space for statements and governing what can and cannot be said. This enables discourse to simultaneously produce both knowledge and power, circulating it through society, thus knowledge and power are entwined, which serves to highlight the importance of societal perceptions and policy representations of early education teachers.

In other news...

Reviewing recent newspaper articles pertaining to early education reveals significant details regarding developments in the early education sector in Ireland, with the government engaging in policy to improve quality of services for children and provide financial support for parents, while continuously failing to address issues regarding working conditions. There are signs of an increased awareness regarding the importance of early 
education but this is not reflected in the "value" placed on those working in the sector. The word "teacher", and the dividends associated with that label, remain absent throughout the discourse. In revealing the consistent absence of the word "teacher" the author is reminded of Fairclough's [8] notion that what is absent from a text may be just as significant as what it contains, particularly when regarded alongside Ball's [2] recommendation that we consider not just whose ideas are being validated, but whose ideas are not being validated. Perhaps the recent emergence of the term "educators" may suggest the direction in which the sector itself hopes to move in the future. The impact of how early education teachers are portrayed in wider societal structures, in policy and media discourse, seems to reflect the current ideology.

It's all in the name...

While this much needed evolution of early education in Ireland is welcomed by many there appears to be an underlying sense of trepidation, as not all early education teachers believe they are equipped with the necessary skills to truly embrace inclusion, the changes in the sector leading them to challenge their competence and question their professional identity. It may be argued that all people have multiple identities connected to both the type of person they are and by how society perceives them. People are defined by their roles in life, whether that's "wife”, "dad", "nurse” or "teacher". Of course, what we need to consider is how we come to be the "self" defined by these roles and who is given the power to define these roles within, and forming, the dominant ideology.

The author suggests that the labels assigned to early education teachers have a significant impact on their professional identity, which in turn plays a vital role in their interaction with the children under their care. While it is necessary and possible for early education teachers to provide the correct balance of care and education, this role will be best performed under a single united identity, established at policy level. It may be worth noting however, Ball's [1] belief that the more ideologically abstract the policy the greater the distance from conception to practice. This is of great interest to me, as is his description of policies as textual interventions into practice and I believe a change at policy level is required to improve the early education sector in Ireland. If we consider the vast volume of research which suggests that quality early education enriches childhood, it is easy to conclude that by providing the best possible experiences in early education it may lead to an enriched society. Establishing an unambiguous profession identity for early education teachers may prove the key to quality and equality in the early education sector. It is worth considering Bowe and
Ball's [4] theory that interpretation can be difficult in the presence of more than one agenda. The government's insistence on focusing on the early education sector, exclusive of those working in the sector, creates two separate agendas. The focus being placed on funding and training to improve the sector seems reminiscent of Ball's [2] suggestion that discourse may idealise solutions to societal problems. If CDA truly is socially committed and increased awareness is the first step towards emancipation [8], this article expresses a desire to push the early education sector ever-closer to that first step and makes no apologies for doing so.

\section{References}

[1] Ball, S. (1994). Education reform: A critical and poststructural approach. Philadelphia: Open University Press.

[2] Ball, S. (2011). Politics and policy making in education: Explorations in sociology. London: Routledge.

[3] Ball, S. and Vincent, C. (2007). 'Making up' the middle-class child: Families, activities and class dispositions. Sociology, 41(6), pp.1061-1077.

[4] Bowe, R. and Ball, S. (1992). Education, markets and professionalism: Some reflections on recent policy developments in England and wales. Melbourne Studies in Education, 33(1), pp.56-62.

[5] Colebatch, H. (2006). Beyond the policy cycle: The policy process in Australia. Sydney: Allen and Unwin.

[6] Corsaro, W. (2000). Early childhood education, children's peer cultures, and the future of childhood. European Early Childhood Education Research Journal, 8(2), pp.89-102.

[7] Edwards, T. and Whitty, G. (1998). School Choice Policies in England and the United States: An Exploration of Their Origins and Significance. Comparative Education, 34(2), pp.211-227.

[8] Fairclough, N. (1995). Critical discourse analysis: The critical study of language. 5th ed. New York: Longman.

[20] Foucault, M. (1972) Archaeology of Knowledge. Hoboken: Taylor and Francis.

[9] Hayes, N. (2010). Childcare? Early childhood education and care? Towards an integrated early years policy for young children in Ireland. Early Years, 30(1), pp.67-78.

[10] Jones, R. (2012). Discourse analysis: A resource book for students. New York, NY: Taylor \& Francis.

[11] Marston, G. (2004). Social policy and discourse analysis: Policy change in public housing. Aldershot, England: Ashgate Publishing.

[12] Meyer, M. and Wodak, R. (2001). Methods of critical discourse analysis. London: Sage. 
[19] Moloney, M. (2014) Breach of trust-getting it right for children in early childhood care and education in Ireland. Early Childhood Policy, Special Issue (17), pp.71-86.

[13] Ready to learn: white paper on early childhood education. (1999). Dublin: The Stationery Office.

[14] Richardson, J. and Gill, R. (1996). Discourse Analysis: Practical Implementation. Leicester: British Psychological Society.

[15] Schweinhart, L., Barnett, W., Belfield, C. and Nores, M. (2005). Updating the economic impacts of the high/scope Perry preschool program. Educational Evaluation and Policy Analysis, 27(3), pp.245-261.

[16] Snow, K. (2006). Measuring school readiness: Conceptual and practical considerations. Early Education \& Development, 17(1), pp.7-41.

[17] Starting strong: Early childhood education and care. (2001). [online] Available at:http://www.oecd.org/education/school/2535215.pdf [Accessed 27 Aug 2016].

[18] Van Leeuwen, T. (2008). Discourse and practice: New tools for critical discourse analysis. Oxford: Oxford University Press. 